\title{
A TEORIA DAS FORMAS DE PLATÃo E A OBJETIVIDADE NO JUÍZO DO CONCEITO DE HEGEL
}

\author{
PLATO'S THEORY OF FORMS AND OBJECTIVITY IN MIND THE CONCEPT OF HEGEL
}

Henrique Raskin*

\section{RESUMO}

Este trabalho busca relacionar o Juízo do Conceito de Hegel com a Teoria das Formas de Platão, ao abordar a questão da objetividade do juízo. Para isso, o artigo, primeiramente, explora a pretensão de Hegel de equivaler forma e conteúdo no seu juízo, em rompimento com a lógica formal; analisa o apriorismo hegeliano, que rejeita concepções subjetivistas do juízo na tradição filosófica; e, por fim, apresenta a objetividade do juízo hegeliano, ao explorar o juízo do conceito que, abandonando o empirismo já em Aristóteles, recupera conceitos platônicos da Teoria das Formas. Assim, este trabalho aponta que o estabelecimento de um juízo objetivo, na filosofia hegeliana, viria a romper com o empirismo, tanto da tradição liberal, quanto de Aristóteles, podendo significar, em parte, a recuperação da filosofia de Platão.

PALAVRAS-CHAVE: Ciência da Lógica. Juízo do Conceito. Teoria das Formas.

\begin{abstract}
This essay seeks to relate Hegel's Judgement of the Notion with Plato's Theory of Forms, by accessing the judgement's objectivity issue. Therefore, the essay, firstly, explores Hegel's claim to equate form and content, disrupting the formal logic; then, analyzes the Hegelian apriorism, which rejects subjectivist conceptions of judgement in the philosophical tradition; and, at last, presents the objectivity in the Hegelian judgement, by exploring the Judgement of the Notion which, by abandoning the empiricism already in Aristotle, recovers platonic concepts of the Theory of Forms. Hence, this essay points that the establishment of an objective judgement, in Hegel's philosophy, would break with the liberal and Aristotelian empiricisms, affording to mean, in part, the recovery of Plato's philosophy.
\end{abstract}

KEYWORDS: Science of Logic. Judgement of the Notion. Theory of Forms.

\footnotetext{
*Doutorando em Filosofia pela PUCRS. E-mail: hraskin@ hotmail.com.
} 


\section{INTRODUÇÃO}

A teoria das formas é um dos grandes legados da ontologia platônica, tendo, ainda nos dias de hoje, espaço reservado nas principais questões da filosofia. Entretanto, nem sempre Platão teve o respaldo que atualmente possui e faz por merecer, dada a relevância filosófica de sua obra. Assim, diz-se que a influência de Platão na história da filosofia é oscilante, uma vez que sua comparação com Aristóteles, em algumas fases da história, trouxe sua subestima e, em outras, sua supremacia. O idealismo alemão de Kant, Fichte, Schelling e Hegel é um dos momentos em que há o renascimento de Platão, sobretudo no que diz respeito à teoria das formas. Como será feito posteriormente neste artigo, podem-se observar diversas referências ao filósofo grego no pensamento iluminista de Kant e, consequentemente, no do movimento idealista alemão em geral. Kant viria a apresentar, na sua transcendentalidade, a relação entre o fenômeno e a ideia, presentes na teoria das formas de Platão; e Hegel, em um movimento intersubjetivo, também se apropriaria das formas platônicas, na construção de sua situação do sujeito no mundo objetivo.

O que este trabalho visa especificamente a abordar, contudo, é de que maneira a Teoria das Formas de Platão aparece no juízo da Ciência da Lógica, de Hegel, principalmente na seção do Juízo do Conceito. O que pretende, portanto, é apresentar de que modo a busca de Hegel pela objetividade, dentro da subjetividade, utiliza as formas platônicas na formação do juízo. Para isso, este artigo dividir-se-á em três seções: a primeira (Hegel e o jogo entre Forma e Conteúdo do Juízo) apresentará o desenvolvimento do juízo em direção à unidade da forma das proposições com seu conteúdo; a segunda ( $O$ Juízo da Necessidade frente à tradição empirista) buscará mostrar que, na objetividade já existente no juízo da necessidade, Hegel apresenta uma crítica ao subjetivismo que permeava, ainda, a filosofia de Kant; e, por fim, a terceira seção (O Juízo do Conceito e a objetividade da Teoria das Formas de Platão) será encarregada de expor a conexão entre o caráter objetivo no dever-ser do juízo de Hegel com a teoria das formas de Platão, expondo a influência do idealismo platônico na Doutrina do Juízo hegeliana ${ }^{1}$.

\footnotetext{
${ }^{1}$ Este artigo é resultado do seminário "Filosofia e interdisciplinaridade IV - A lógica do conceito de Hegel: a doutrina de Hegel do conceito, do juízo e do silogismo", ministrado pelos professores Agemir Bavaresco, Christian Iber e Federico Orsini, em 2015/1 na PUCRS. Como consequência, grande parte do conteúdo desse artigo é fruto de comentários, discussões e leituras que ocorreram na, e para a disciplina, das quais as anotações feitas pelo aluno tiveram implicação direta na construção do trabalho.
} 


\section{HEGEL E O JOGO ENTRE FORMA E CONTEÚDO DO JUÍZO}

Na Ciência da Lógica, a "Doutrina do conceito" se divide basicamente em três grandes seções: o Conceito, o Juízo e o Silogismo, divisão essa que se mostra revolucionária dentre o contexto da história da filosofia. Revolucionária porque, desde Aristóteles, tem-se na

lógica apenas um instrumento para o pensar. É clássico o exemplo aristotélico amplamente utilizado do silogismo sobre Sócrates: sabendo-se que todos os homens são mortais, e que Sócrates é um homem, pode-se concluir que Sócrates é mortal. Hegel, em contrapartida, não restringe a lógica a essa instrumentalidade do raciocínio. Para o filósofo, por meio da dialética, o conceito 'Sócrates', por si só, já constituiria o pensamento, em processo de determinação. Por isso, em vez de consolidar sua lógica no silogismo, Hegel estabelece esses três diferentes graus (conceito, juízo e silogismo), progressivos em relação a determinação, qualificados por meio da tríade universal-particular-singular.

Instituindo sua dialética enquanto epistemologia, Hegel enfaticamente demonstra, na Doutrina do Conceito, a relação entre as categorias universal, particular e singular, em cujo sistema relacional determinam a identidade dos conceitos. Esse é o momento em que ocorrem os jogos de contraposição de sujeitos com predicados, pois o pensamento, ao realizar juízos, nada mais faz que estabelecer relações entre diferentes conceitos, situando-os em níveis de universalidade, particularidade e singularidade. É a partir dessas relações conceituais que Iber (2015a) situa a forma do juízo:

\footnotetext{
O conceito condiciona, portanto, a forma lógica do juízo. Em um segundo passo é esclarecido o que é um juízo e o que nele ocorre. Primeiramente os extremos do juízo são tematizados, em seguida, a relação dos extremos do juízo. O juízo é expresso numa proposição; e uma proposição contém habitualmente sujeito e predicado. Mas somente uma relação determinada do sujeito e do predicado, na qual estes se comportam um para com o outro conforme espécie de determinaçõos conceituais, torna uma proposição em juízo.
}

Para tanto, Hegel divide os juízos em quatro formas, que se suprassumem uma à outra. São elas: o juízo do ser-aí (positivo, negativo, infinito), o juízo da reflexão (singular, particular, universal), o juízo da necessidade (categórico, hipotético, disjuntivo) e, por último, o juízo do conceito (assertórico, problemático, apodítico). Essas conseguintes suprassunções, a partir do juízo positivo do ser-aí, até o juízo apodítico do conceito, significam a progressão do estabelecimento de um juízo conceitualizante e raciocinante. No que diz respeito à conceitualização, vê-se, no juízo hegeliano, o jogo da diferença entre forma e conteúdo, em 
que, por um lado, observa-se em sua forma a combinação entre universalidade, particularidade e singularidade e, por outro, enxerga-se no conteúdo o movimento de negação, capaz de conceitualizar por meio da delimitação negativa. Nesse sentido, tem-se os juízos sintéticos a priori. Já no que concerne ao caráter raciocinante do juízo, mostra-se permear por suas diferentes formas o jogo entre sujeito e predicado, em cuja justaposição tanto as diferenças quanto as semelhanças de seus conteúdos mostrar-se-iam expostas. Passemos, então, a brevemente analisar essa transição do juízo do ser-aí ao juízo do conceito, ao qual será dada maior atenção neste artigo, posteriormente.

No juízo do ser-aí, a cópula 'sujeito é predicado' os une sob a forma 'o singular é universal'. A correspondência forma-conteúdo do juízo não ocorre, justamente porque seu conteúdo é inverso, significando 'o universal é singular'. No exemplo utilizado por Hegel 'a rosa é vermelha', vê-se claramente essa desconexão entre forma e conteúdo. No juízo positivo, por exemplo, tem-se, formalmente, que a rosa, dentre muitos outros possíveis sujeitos, é vermelha: poderia também ser vermelho um carro, ou um sapato. O problema que é mostrado, contudo, no juízo negativo, é que essa mesma rosa, ao ser vermelha, não é branca, tampouco azul, ou verde. Essa negação 'a rosa não é branca', com isso, expõe a diferença entre forma e conteúdo na proposição do juízo do ser-aí, pois seu conteúdo mostra que o singular (rosa) passa a conter o universal (vermelho), sob a forma da particularidade. Em vez de apontar a rosa como vermelha - em detrimento de outros sujeitos que são vermelhos também, o conteúdo do juízo do ser-aí acusa a rosa de ser vermelha, em detrimento de outras características que ela poderia ter (ser branca, por exemplo). Em termos de conteúdo, é o singular (rosa) que contém o universal (vermelho), e não o contrário, como a forma sugere. Vermelho, passa a ser particularidade da rosa (singular) ${ }^{2}$.

Porém, ainda no juízo do ser-aí, o juízo infinito mostrará que o sujeito continua sendo o sujeito, e o predicado continua sendo o predicado, sendo um separado do outro: muitas coisas são vermelhas, como a rosa (sujeito), e há muitas características além do vermelho na rosa (predicado). Essa afirmação conduzirá tanto à tautologia infinita 'a rosa é uma rosa', quanto à indeterminação 'a rosa não é um elefante'. No juízo infinito, a cópula 'é' entre

\footnotetext{
2 "Pode-se notar a) que, aqui, surge a particularidade para o predicado, do que já se falou anteriormente; só que aqui ela não é posta através da reflexão exterior, mas se originou por meio da relação negativa mostrada no juízo, b) Essa determinação surge aqui somente para o predicado" (HEGEL, 2015, § 30).
} 
sujeito e predicado se mostra ineficaz, pois ela não mais pôde relacionar sujeito e predicado em uma relação de determinação ${ }^{3}$.

Por isso, Hegel introduz o juízo da reflexão, em que o sujeito é subsumido, passando a ser subordinado ao predicado, uma vez que o juízo do ser-aí se conduziu à indeterminidade. A dualidade sujeito-predicado se mantém nessa forma de juízo, porém a proposição 'essa planta é medicinal' mostra que o universal 'medicinal' particulariza o sujeito, diferentemente do juízo anterior, onde a forma mostrava o contrário. $\mathrm{O}$ cerne do juízo reflexivo é que a forma ' $\mathrm{S}$ é P' expõe a essência da identidade do sujeito ${ }^{4}$ : o predicado subordina o sujeito. Entretanto, ainda não se mostrou consistente o juízo, nos quesitos da conceitualização e do caráter raciocinante, pois a planta não conceitua o universal 'medicinal'. O caminho inverso dessa proposição não é verdadeiro, pois por mais que a característica medicinal conceitue a planta (e, ainda assim, apenas algumas plantas), a planta não demonstra a essência de 'medicinal'. Há outros possíveis sujeitos medicinais, além de plantas.

Nesse aspecto, o juízo da necessidade suprassume o da reflexão, pois nele aparece uma relação necessária entre sujeito e predicado. O primeiro, o juízo categórico, explicita a “identidade substancial” do sujeito, pois a relação se dá entre gênero (particular) e o universal. 'Ouro é metal', por exemplo, implicitamente significa que ouro é necessariamente um metal, não podendo haver ouro que não fosse metal. Não somente, a substancialidade se mostra presente, pois ouro não é apenas um singular: é, sobretudo, um particular, um gênero. $\mathrm{O}$ problema desse juízo é que não é apenas 'metal' o que caracteriza o ouro; em outras palavras, 'metal' não é suficiente (ainda poder-se-ia afirmar que ouro é um metal precioso). Essa relação entre ouro e metal, portanto, mostra-se deficitária, pois o conteúdo do ouro não se apresenta nessa relação de necessidade ${ }^{5}$. Surge então a seguinte pergunta: seria possível afirmar de que forma o sujeito (particular) se diferencia do seu predicado (universal)? Hegel

\footnotetext{
${ }^{3}$ Conforme Orsini (2015a, p. 7): “A ideia básica é que o juízo infinito mostra a necessidade de uma reflexão do juízo que não pode ser ulteriormente explicada sem romper com a forma do juízo do ser aí, na medida em que ela é essencialmente caracterizada por uma qualitativa alteridade dos termos relacionados. Em particular, esta crítica resulta destinada tanto ao juízo negativamente infinito quanto ao juízo positivamente infinito. No primeiro, está expressa só a diferença, mas não a identidade ou relação positiva entre sujeito e predicado. No segundo, está presente só a identidade, mas não a diferença ou relação negativa entre os extremos.”

${ }^{4}$ Hegel $(2015$, §45) diz que "o conceito determina o ser aí primeiramente para determinações da relação, para continuidades delas mesmas na multiplicidade diversa da existência, - de modo que o verdadeiramente universal é, certamente, a essência interior dela, mas no aparecimento, e essa natureza relativa ou também a característica dela ainda não é o que é em e para si dela" (HEGEL, 2015).

${ }^{5}$ Iber (2015b, p. 1) explica essa deficiência do juízo categórico ao colocar que "o sujeito é mais específico do que o predicado. [...] O predicado é como um grande saco, no qual se pode colocar a coisa - com muitas outras".
} 
acusa que não, pois o ouro, junto a todos outros metais, se encontra nessa grande categoria de 'metais'.

Ainda no juízo da necessidade, Hegel apresenta o juízo hipotético, em que estabelece relações sujeito-predicado sob a forma 'se A é, então necessariamente B é'. O fio condutor da relação é justamente o conteúdo, que possui papel central nessa proposição; 'se existe o pai, então necessariamente o filho existe'. Não há pai sem filho, e não há filho sem pai, necessariamente ${ }^{6}$. É o conteúdo de 'pai' e 'filho' que os conecta nessa relação necessária, porém, por outro lado, o conteúdo também se mostra descompromissado com a realidade, visto que o que importa é a relação entre A e B, pautada no conteúdo. 'Marte é uma estrela tanto quanto o Sol é um planeta': essa expressão mostrar-se-ia formalmente correta, no que diz respeito ao conteúdo, porém seu conteúdo é falso. Hegel, assim, constitui seu juízo hipotético, justamente porque essas comparações definem o sujeito ao mesmo tempo em que apresentam crítica à lógica formal, mostrando sua necessidade de ser suprassumida ${ }^{7}$. É quando Hegel introduz o juízo disjuntivo, dentro do juízo da necessidade.

O juízo disjuntivo demonstra-se superior aos outros, pois nele já se pode identificar a unidade entre forma e conteúdo. A expressão 'o poema é necessariamente ou épico, ou lírico, ou dramático' exemplifica a particularização do gênero 'poema' presente nessa forma de juízo. Primeiramente, há uma identidade positiva entre o particular e o universal, pois o poema é tanto épico, quanto lírico, quanto dramático. Essas características universais definem o sujeito. Em segundo lugar, existe uma relação disjuntiva no predicado, porque o poema (sujeito) pode ser ou épico, ou lírico, ou dramático. Esses predicados são diferentes e, portanto, não podem ser codeterminantes a um singular. Podem, porém, determinar o gênero 'poema', enquanto totalidade. A necessidade consiste, todavia, no fato de que o gênero necessariamente é um ou outro predicado e, portanto, a relação negativa de exclusão entre as espécies épica, lírica e dramática estabelece uma forma de relação entre elas, pois igualmente são espécies que compõem a totalidade do gênero 'poema'. Nessa relação, tem-se que o

\footnotetext{
6 "O juízo hipotético não contém que A é ou que B é, mas apenas: se um é, então o outro é; apenas a conexão dos extremos, não eles mesmos, está posta como [aquilo] que é. Antes, cada um está posto, nessa necessidade, como igualmente o ser de um outro" (HEGEL, 2015, § 67).

7 "A deficiência do juízo hipotético - e por causa disso a lógica formal se refere a ele - é que a relação necessária de A e B permanece, conforme o conteúdo, indeterminada. O que ambos, do ponto de vista do conteúdo, têm a ver um com o outro, fica em aberto. Essa espécie de necessidade exclui o conteúdo. A independência da forma da necessidade do conteúdo é aquilo que do juízo hipotético interessa à lógica formal” (IBER, 2015b, p.2).
} 
sujeito equivale, então, ao predicado ${ }^{8}$. Assim, Hegel finalmente encontrou a correspondência entre forma e conteúdo em seu juízo.

\section{O JUÍZO DA NECESSIDADE FRENTE À TRADIÇÃO EMPIRISTA}

O juízo da necessidade, ao combinar forma e conteúdo, já havia introduzido ao juízo hegeliano, em geral, a ideia de universalidade objetiva. Isso porque, anteriormente, no juízo do ser-aí e no juízo da reflexão, o movimento sob a fórmula 'sujeito é predicado' caracterizava o sujeito, sem totalmente defini-lo. Em 'a rosa é vermelha' ou 'a planta é medicinal' vê-se claramente essa deficiência a ser superada. A rosa não é apenas vermelha; tampouco, saber a essência medicinal da planta não é suficiente para encontrar objetividade na construção lógica do juízo. Dependendo do agente que julga, diferentes juízos podem ser feitos sobre a rosa e a planta: a rosa poderia ser cheirosa, e a planta poderia ser verde. Apenas no juízo da necessidade, mais especificamente no juízo disjuntivo, é que se tem afirmações universais: 'o poema é necessariamente ou épico, ou lírico, ou dramático'. A equivalência entre forma e conteúdo nesse juízo expressa sua objetividade, pois a dualidade centrada no sujeito de 'a rosa é vermelha' e 'a planta é medicinal' não mais se vê aqui.

Para Hegel, já não mais importa quem afirma que 'o poema é necessariamente ou épico, ou lírico, ou dramático', visto que a objetividade sobre a conceitualização do 'poema', nesses termos, independe da proposição feita pelo agente que julga. $\mathrm{O}$ poema, cientificamente e objetivamente pensado, só pode ser épico, lírico ou dramático, em seu conceito lógico. Assim, o juízo de Hegel passa a contemplar o objeto 'poema' e não mais o agente que julga9 como o fez a tradição empirista desde Aristóteles até o Idealismo Alemão ainda permeado em Kant.

\footnotetext{
8 "A universalidade idêntica, objetiva aparece, por isso, como o refletido em si frente à forma inessencial, como conteúdo, o qual tem, porém, nele mesmo, a determinidade da forma; por um lado, como a determinidade simples do gênero, e, por outro lado, precisamente essa determinidade como desenvolvida na sua diferença, desse modo, ela é a particularidade das espécies e a totalidade delas, a universalidade do gênero" (HEGEL, 2015, $\S 69)$.

${ }^{9}$ Já no proêmio da "Doutrina do Juízo", Hegel conceitua o juízo em sua própria relação consigo mesmo. Urteil, separação originária, expressa a concepção de uno original, ao qual nada se agrega por meio do juízo. Pelo contrário, o juízo mais seria a representação dessa realidade lógica existente a priori, anterior à experimentação sensível - à qual Kant depositava os juízos sintéticos. "Ele [o juízo] é, nesse aspecto, a separação originária [ursprüngliche Teilung] do uno original; a palavra juízo [Urteil] se refere, com isso, àquilo que ele é em e para si. Mas o fato de que o conceito no juízo é como aparecimento, na medida em que seus momentos alcançaram autonomia nele, - isso é o lado da exterioridade no qual a representação se mantém" (HEGEL, 2015, § 5).
} 
Aristóteles seria o pai da corrente epistemológica do empirismo, ao combater a ideia de conhecimento inato e a teoria das formas de Platão. Aristóteles viria a introduzir a concepção da percepção, sem a qual não se poderia alcançar o conhecimento da realidade. Entretanto, não coube ao estagirita estabelecer a relação entre percepção (aisthêsis), indução (epagôgê) e intelecto (nô̂s), embora os abordasse enquanto reconhecimento da realidade. Höffe (2008, p. 83) demonstra que: “como o conhecimento de princípios corresponde é aplicado na percepção, inclina-se à interpretação empirista de que, em seguimento a isso, os conceitos universais são obtidos a partir da percepção por meio de mera abstração".

A tradição do empirismo inglês, de Locke, Berkeley e Hume, radicaliza a visão Aristotélica de conhecimento da realidade ao romper com a metafísica medieval e moderna. Hume, que representa seu auge, refutava a tríade 'identidade, não contradição e causalidade' da metafísica, em que os dois primeiros embasavam a ideia de essência, e o terceiro a de causalidade. O que Hume viria a introduzir é, em contrapartida, que o conhecimento se daria pela associação de sensações, percepções e impressões, captadas pelos sentidos e armazenadas na memória. Em vez de essência, o que existe são diferentes objetos, cujas semelhanças percebidas pelos sujeitos determinam seu agrupamento em conjuntos; e, em vez de causalidade, há a captação de percepções sucessivas, cuja repetição dá apenas a impressão de causalidade (CHAUÍ, 2000). Locke, no Ensaio sobre o entendimento humano (1690), já havia conceituado o juízo a partir das experimentações sensíveis de felicidade e miséria. "As coisas são, portanto, boas ou más somente em relação ao prazer e à dor. Chamamos bem àquilo que for capaz de causar e aumentar em nós o prazer ou diminuir a dor." (LOCKE, 1999, p. 299).

Kant, ao introduzir o idealismo alemão, conservava elementos da tradição do empirismo, identificados na sua distinção entre juízos analíticos e juízos sintéticos. Ambos os juízos apresentam a estrutura 'sujeito é predicado', porém o tipo de relação entre esses elementos os qualificam como analíticos ou sintéticos. O primeiro tipo tem no predicado a explicitação do conteúdo do sujeito. "O triângulo é uma figura de três lados" exprime essa ideia, pois um triângulo possui três lados, e uma figura que tem três lados é um triângulo. Já o juízo sintético kantiano possui no predicado um novo dado acrescentado para o sujeito como, por exemplo, em "Sócrates é filósofo". Esse juízo mostra suas raízes empiristas, pois só pode ser concebido por meio da experiência sensorial a posteriori. A Kant, apenas o juízo analítico preenche as condições para possuir valor teórico (universal, necessário, verdadeiro), pois 
sendo o juízo sintético obtido a posteriori, ele é relativo e não necessariamente verdadeiro, remetendo à experiência no sentido de Locke e Hume (CHAUÍ, 2000).

Hegel confronta essa tradição do pensamento com seu juízo da necessidade, no sentido em que rompe com a subjetividade presente em Aristóteles, ainda remanescente no empirismo inglês, e presente até mesmo em Kant. Dessa maneira, Hegel enfaticamente diferencia seu juízo disjuntivo de um juízo empírico ${ }^{10}$. Como demonstrado anteriormente, o juízo disjuntivo possui na cópula entre sujeito e predicado uma relação de necessidade: 'o poema é necessariamente ou épico, ou lírico ou dramático'. É o fato de possuir uma dessas três espécies que o faz poema - e essa categorização em três espécies particularizantes expressa a totalidade do gênero poema. Deve-se ressaltar, ainda, que não há nada além dessas três espécies para caracterizar o poema: é ou um ou outro.

Por outro lado, o juízo empírico disjuntivo tomaria, como partida, a percepção subjetiva do agente que julga para a complementação do sujeito no predicado - e não a sua universalidade concreta (como no poema, que só pode conceitualmente ser épico, lírico ou dramático). $\mathrm{Na}$ expressão 'A é ou $\mathrm{B}$, ou $\mathrm{C}$, ou $\mathrm{D}$, ou $\mathrm{E}$, etcetera', não se tem a noção de totalidade do sujeito A, e sim, diversas possibilidades de complementação para esse sujeito. 'Roberto ou dorme, ou corre, ou canta, ou caminha, etc' não expressa a totalidade de Roberto, tampouco o define. Além disso, os predicados não são necessariamente um ou outro, nem tampouco se excluem: Roberto pode caminhar e cantar ao mesmo tempo, por exemplo.

\begin{abstract}
Se o gênero fosse uma universalidade abstrata como nos juízos do ser aí, então as espécies deveriam ser tomadas como diversas e indiferentes uma frente à outra; porém, ele [o gênero] não é aquela universalidade exterior, surgida apenas da comparação e do deixar à parte, mas sim a universalidade imanente e concreta delas. (HEGEL, 2015, §70).
\end{abstract}

Ao realizar sua crítica à disjunção empírica, Hegel aponta que o juízo empírico disjuntivo não possui necessidade, ao ser tomado como universalidade exterior. É, portanto, importante reiterar o caráter objetivo do juízo disjuntivo de Hegel, que aborda um sujeito em sua objetividade com seu predicado. O juízo disjuntivo, portanto, independe da empiria, e independe do agente que o estabelece. Contudo, o juízo disjuntivo ainda se mostra

\footnotetext{
10 "Um juízo empírico disjuntivo é destituído de necessidade; A é ou B ou C ou D etc., porque as espécies B, C, D etc. são encontradas; através disso, não se pode propriamente expressar nenhum ou-ou [como no juízo disjuntivo da necessidade], pois tais espécies constituem, por assim dizer, uma completude subjetiva; uma espécie certamente exclui a outra, mas o ou-ou [do juízo disjuntivo da necessidade] exclui toda e qualquer outra e encerra em si uma esfera total.” (HEGEL, 2015, § 70).
} 
insuficiente, precisando ser suprassumido pelo juízo do conceito, que além de conceber objetividade a priori na relação sujeito-predicado, agregará valor a essa cópula.

No juízo disjuntivo, por mais que se observe a essência do sujeito universal (poesia) por meio das particularidades predicativas (espécies), ainda há a carência no que diz respeito à singularidade do conceito $^{11}$. Fala-se, por exemplo, do sujeito, enquanto universalidade particularizada por meio do predicado, sem incluir a singularidade do conceito. Hegel, entretanto, consegue superar esse problema no juízo do conceito, ao relacionar tanto singularidade, quanto particularidade e universalidade.

\title{
O JUÍzO dO CONCEITO E A OBJETIVIDADE DA TEORIA DAS FORMAS DE PLATÃO
}

É a partir da objetividade introduzida pelo juízo da necessidade, que o juízo do conceito surge dividido em juízo assertórico, problemático e apodítico. Contudo, se no juízo da necessidade a objetividade se dava por meio da correspondência entre forma e conteúdo e, assim, da igualdade conceitual entre o sujeito e o predicado, no juízo do conceito a objetividade se alia ao caráter valorativo no juízo que, para Hegel, interliga-se ao dever-ser do objeto.

O juízo assertórico pode ser construído de acordo com a seguinte estrutura: 'esta casa é ruim' ou 'esta ação é boa'. Há, claramente, uma concepção avaliativa nessas afirmações que suprassume o juízo da necessidade; contudo, como aponta Orsini (2015b), existe uma perda da objetividade no juízo assertórico, objetividade essa que já se mostrava presente no juízo disjuntivo.

\begin{abstract}
A autonomização de todos os momentos do Conceito faz como que o primeiro passo do juízo do conceito para além do juízo da necessidade se torne, para assim dizer, uma recaída do juízo para trás da "universalidade concreta" do juízo disjuntivo, porque o juízo assertório se apresenta em uma forma não desenvolvida, a saber, "na forma de extremos aos quais falta ainda o próprio conceito como unidade posta, que os relaciona". (ORSINI, 2015b, p. 4).
\end{abstract}

\footnotetext{
${ }^{11}$ Conforme explica Iber (2015b, p. 3): “o juízo disjuntivo tem ainda uma deficiência, que Hegel tematiza primeiramente no preâmbulo ao juízo do conceito (cf. TW 6, 345): não se torna saliente como o universal e o particular se comportam [em relação] ao singular, cujas determinações conceituais eles são. Esse tema é discutido pelo juízo do conceito. Enquanto essa questão não está esclarecida, a determinação substancial da essência do singular permanece tão-somente uma afirmação".
} 
No juízo do conceito, em geral, Hegel objetivamente estabelece a valoração do sujeito, enquanto bom ou ruim. Todavia, no juízo assertórico, essa objetividade ainda não se mostra explícita, como deveria. Formalmente, o juízo assertórico não se diferencia do que seria um juízo subjetivo no sentido empirista ou kantiano. Falta no juízo assertórico, para Hegel, o "terceiro exterior", componente que justifica o fato da casa ou da ação, por exemplo, serem boas ou ruins. Enquanto não há essa justificação que expõe a objetividade do juízo do conceito, o juízo assertórico não se diferencia formalmente das opiniões subjetivas ${ }^{12}$.

Por esse motivo, o juízo problemático suprassume o juízo assertórico, pois segundo Orsini (2015b, p. 5), somente no juízo problemático "pode ser explicitado que a contingência da relação entre singular e universal não depende de um juiz exterior, mas na própria constituição do singular". Ou seja, a contingência que define a bondade ou a ruindade de um juízo valorativo não depende da percepção terceira de quem emite um juízo, como no subjetivismo da tradição empírica. A contingência, então, se dá no conceito do sujeito singular do juízo do conceito. O bom ou o ruim é um juízo objetivo, inserido no conceito da casa ou da ação em questão.

O juízo problemático, portanto, estabelece que o problema de um juízo equivocado não está na valoração do sujeito enquanto bom ou ruim. O problema, assim, está na cópula 'É', que estabelece a relação entre sujeito e predicado. Por esse motivo, para Hegel, 'a casa ou uma casa é boa' não é suficiente; deve ser considerado o 'dependendo de como ela está constituída'. Essa constituição da casa é o que determina o sujeito do juízo, para que então possa ser estabelecida uma cópula justa que corresponda o sujeito singular ao predicado universal (por meio da particularidade).

O juízo apodítico soluciona esse problema e, consequentemente, encerra o que Hegel nomeia de Doutrina do Juízo, pois, nele, encontram-se presentes a singularidade, particularidade e universalidade, combinados na equivalência da forma e do conteúdo. Mantem-se constitutivo no juízo apodítico o caráter objetivo do juízo da necessidade; porém, é também agregada a ele a ideia de comparação entre o sujeito e seu dever-ser, já presente nos juízos assertórico e problemático, ainda que implícito ou constitutivo a um 'terceiro ainda exterior'. A novidade no juízo apodítico, entretanto, mostra-se na explicitação do porquê da

\footnotetext{
${ }^{12}$ Segundo Orsini (2015b, p. 2), "o juízo da modalidade, juízo que, para Hegel, a lógica transcendental assume segundo lemas da lógica formal, não expressa o que a coisa é em e para si, mas o que o conceito subjetivo dela é em relação com o pensar como "entendimento exterior" à coisa".
} 
correspondência do sujeito ser boa ou ruim em relação ao seu dever-ser ${ }^{13}$. Essa é a particularidade do sujeito que faltava nos juízos anteriores. Dessa maneira, forma-se a estrutura do juízo apodítico: 'a casa constituída assim e assim é boa', onde 'a casa' é o sujeito singular (fala-se em uma específica casa), 'constituída assim e assim' é a sua particularidade (pois a caracteriza de tal forma particular), e 'é boa' é a exposição do universal, que explicita a correspondência objetivamente universal entre o sujeito (singular e particular) e seu conceito (conceito de casa como ela deve ser).

'A casa constituída assim e assim é boa' ou 'a ação constituída assim e assim é justa', enquanto juízos apodíticos, seria a última das categorias de juízo que Hegel trabalhou na Doutrina do Juízo. Como dito anteriormente, seria o encerramento da seção sobre juízo na obra sobre a lógica de Hegel, porque tal juízo seria capaz de estabelecer de forma equilibrada a tríade lógica do universalismo, particularismo e singularidade, ao mesmo tempo em que encontraria equivalência de forma e conteúdo, bem como de sujeito e predicado. Todavia, há de se salientar que o juízo apodítico tem sua grande importância no fato de que, além de ser a suprassunção de todas as formas de juízo apresentadas por Hegel, é também uma crítica ao empirismo de Aristóteles, Locke, Hume e Kant, principalmente, que ressalta a ideia de subjetivismo do agente no juízo. Essa objetividade de Hegel, que contesta a tradição empirista, poderia encontrar suas bases ainda nas formas de Platão, que instituía o idealismo antes da virada empirista de Aristóteles.

Há uma forte influência platonista no movimento do idealismo alemão em geral, porém em Hegel a questão da objetividade da teoria das formas se mostra evidente na Doutrina do Juízo. Kant já havia recuperado de Platão a diferença entre o mundo das coisas sensíveis e o mundo inteligível com o transcendentalismo, que traduziria a questão para fenômeno e Coisa-em-si. Contudo, Kant repousava a razão no agente que observa o mundo. Hegel, ao adotar Platão, externaliza a razão do sujeito, que não mais tem o poder de construir juízos apenas subjetivamente. Assim, mesmo na subjetividade, poderia ser encontrada a objetividade da razão, por meio da relação entre o sujeito da proposição e o seu dever-ser. Por isso que, na filosofia hegeliana, essa possível atualização da teoria das formas de Platão viria a corroborar a construção de uma crítica à subjetividade presente ainda em Kant.

\footnotetext{
${ }^{13}$ Hegel $(2015, \S 87)$ exprime que “então, aqui é o universal que é ele mesmo e se continua através do seu oposto e só é universal como unidade com esse. - Um tal universal, como os predicados bom, apropriado, correto, etc., tem como fundamento um dever e contém, ao mesmo tempo, o corresponder do ser aí; não aquele dever ou o gênero por si, mas é esse corresponder que é a universalidade a qual constitui o predicado do juízo apodítico".
} 
A teoria das formas de Platão consiste na existência de dois mundos separados um do outro: o mundo inteligível (Formas) e o mundo sensível. Entretanto, em Parmênides, Platão passa a abordar o problema da participação, onde aparece a maneira com que "as Formas fazem-se presentes nas coisas sensíveis" (SOARES, 2001, p. 81). Soares aponta que esse problema, já vindo de A República, remonta a "dois planos ontológicos separados", onde as coisas sensíveis particulares participam das Formas universais, possuindo, assim, o mesmo nome. Partindo disso, Soares (2001, p. 136) diz que:

Tendo em vista a exigência realista do pensamento platônico, o raciocínio que segue é: se existem nomes abstratos, os quais empregamos no pensamento e no discurso falado, e que têm como conteúdo um caráter geral uno, este não pode ser apenas um conceito, mas deve ser uma realidade, em outras palavras, uma Forma.

A existência da Forma, nesse aspecto de Platão, aponta para a universalidade conceitual que Hegel aborda na Doutrina do Juízo, que está diretamente conectada ao apriorismo radical presente em sua obra. Partindo-se do princípio de que todo o juízo hegeliano é construído aprioristicamente, ele não mais é subjetivo ao repousar na experiência individual (a posteriori), podendo ser, então, universal. Nesse sentido, Platão aborda a ideia de participação, mesmo que de diferentes maneiras no decorrer de sua obra; porém, ainda que distintas, elas não se dissociam de uma concepção idealista a priori. Por mais que, em Parmênides, Platão acesse a teoria do conhecimento das Formas por meio de "realidades aprendidas pelo pensamento, pelo discurso, [e] pela razão", o Platão da maturidade desenvolve uma diferente abordagem. Em Mênon, Fedro e Fédon, Platão utiliza-se da teoria da reminiscência, relacionada à imortalidade da alma, que, justamente por ser imortal e divina, residia na região das Formas antes de nascer. Por esse motivo, os seres humanos seriam capazes de conhecer e contemplar as Formas desde antes de sua experiência na terra, relembrando-as e aplicando seus conceitos a partir do mundo sensível. Já na República, em vez da reminiscência, Platão aborda o conhecimento das Formas através da intuição direta. E, no Sofista, a linguagem possui papel central, pois os nomes remetem diretamente às Formas, uma vez que o devir das coisas sensíveis não se mostraria suficientemente fixo para uma denominação objetiva da realidade (SOARES, 2001, p. 137-138).

Por esse motivo, Gadamer (1988) ressalta que Hegel reconhece em Platão o surgimento da dialética especulativa, ao "ter atribuído ao pensamento uma situação de independência que o permite aspirar a conhecer a verdade da realidade na universalidade pura 
do pensar" (GADAMER, 1988, p. 15, tradução nossa). Remetendo à relação conceito-Coisaem-si, ou Forma-mundo sensível, Gadamer (1988, p. 15-16, tradução nossa) continua:

\footnotetext{
O que faz Platão é algo mais que se limitar a confundir o particular [...], para assim deixar que surja de forma mediada o universal: porém, pelo contrário, [ele] aspira a contemplar o universal (aquele que deve valer como determinação), tomado puramente em si mesmo, o que significa, segundo Hegel, mostrá-lo em sua unidade com seu contrário.
}

Nesse sentido, Hegel recupera a objetividade no juízo, frente ao juízo subjetivista da tradição empirista. Como em Platão, que explicava a compreensão do mundo sensível por meio das semelhanças com as Formas inteligíveis, que eram objetivas, em Hegel o juízo centraliza no conceito a correspondência entre o sujeito (ser) e o predicado (dever-ser). Hegel, da mesma forma, reconhece na realidade justamente a diferença entre os seres e seu dever-ser que, por meio do juízo, será objetivamente exteriorizada. 'A casa constituída assim e assim é boa' especificamente compara a casa singular e particularizada, observada pelo agente que julga a casa, em relação ao seu conceito (ou como uma casa deve ser de acordo com seu conceito). A objetividade se apresenta no fato de que esse que julga apenas retrata a realidade, pois ser a casa boa ou não não é um juízo relativo ou subjetivo, pertencente àquele que a observa. A correspondência do ser com seu dever-ser já está dada objetivamente, pois se encontra no conceito de casa, por exemplo.

Por isso, resta a pergunta: que papel possui o agente que observa e julga, no juízo de Hegel? Se a sua subjetividade sensível apenas exprime a objetividade existente na correspondência do ser com o seu dever-ser, poder-se-ia afirmar que o juízo humano é irrelevante frente à realidade? $\mathrm{O}$ idealismo em que o conceito possuía o poder de gerar a realidade, havia se perdido, em Hegel. Entretanto, se em Kant, o dever-ser se mostrava externo às coisas, em Hegel, o dever-ser passa a ser imanente a todas as coisas, pois se encontra em seu conceito. Dessa forma, Hegel concilia subjetividade e objetividade, ao passo em que deposita no juízo a objetividade, em que tudo passa a ser em relação ao seu próprio dever-ser subjetivo imanente.

\section{CONSIDERAÇÕES FINAIS}

A objetividade que Hegel deposita no juízo o diferencia da tradição filosófica que até então projetava no agente sensível a capacidade de julgar o mundo ao seu redor. Hegel, 
contrariamente, busca estabelecer o juízo como o processo de determinação dos conceitos que se relacionam sob a cópula 'é' da relação entre sujeito e predicado - conceitos esses objetivados, independentes do agente que julgava bondade e justiça nas coisas e ações, por exemplo, baseando-se na empiria e subjetividade.

Com isso, Hegel remonta à universalidade e objetividade que o empirismo havia tirado de foco, encontrando em Platão referências de universalidade sobre a compreensão do mundo, conforme este artigo buscou explanar. Assim, no juízo de Hegel, vê-se nas qualidades bondade, justiça, ruindade, injustiça não predicações apontadas pelo agente que julga com base em sua experiência particular. Pelo contrário, o juízo de Hegel, que exprime bondade, justiça, ruindade, injustiça, dentre outros, expressa, sobretudo, a universalidade desses predicados, cuja valoração está na correspondência do sujeito com seu dever-ser.

Portanto, 'a casa constituída assim e assim é boa' significa, sobretudo, que a casa singular, constituída particularmente de alguma forma, é boa no que corresponde ao seu dever-ser, imanente ao seu conceito. Essa correspondência do ser com dever-ser, por contrariar o dever-ser kantiano, que exprime externalidade, e por também ir de encontro com a subjetividade do juízo no empirismo, viria a buscar suas raízes ainda em Platão, que desenvolvera a teoria das Formas.

O reconhecimento do mundo sensível se dar pela reminiscência, pela intuição ou pelo pensamento, em relação ao mundo inteligível das Formas, reaparecerá no que Hegel conceitua logicamente como o apriorismo, condição para a universalidade e objetividade dos juízos. Assim, pode-se dizer que, na objetividade do juízo de Hegel, o agente que julga perde sua importância em relação àquela que tinha na tradição empirista. Nem por isso, contudo, ele deixa de contemplar a realidade tal como ela é; o agente, em Hegel, apenas se independentiza das determinações sensoriais.

\section{REFERÊNCIAS}

CHAUÍ, Marilena. Convite à filosofia. São Paulo: Ática, 2000.

GADAMER, Hans Georg. La Dialectica de Hegel. Madrid: Cátedra, 1988.

HEGEL, G.W.F. Ciência da lógica. Tradução Christian Iber, Marloren Miranda, Michella Bordignon, Frederico Orsini e Agemir Bavaresco. Porto Alegre, 2015.

HÖFFE, Otfried. Aristóteles. Porto Alegre: Ed. Artmed, 2008. 
IBER, Christian. Resumo: o proêmio da doutrina do juízo. Seminário PUCRS/PPGFilosofia, 30 mar. 2015a.

IBER, Christian. Resumo: O juízo da necessidade: a. O juízo categórico, b. o juízo hipotético, c. o juízo disjuntivo (tema 6). Seminário PUCRS/PPGFilosofia, 01 jun. 2015b.

LOCKE, John. Ensaio sobre o entendimento humano. Tradução Eduardo Abranches de Soveral. Lisboa: Ed. Fundação Calouste Gulbenkian, 1999.

ORSINI, Federico. Apresentação do juízo negativo e do juízo infinito. Seminário PUCRS/PPGFilosofia, 13 abr. 2015a.

ORSINI, Federico. O juízo do Conceito: preâmbulo e juízo assertórico. Seminário PUCRS/PPGFilosofia, 01 jun. 2015 b.

SOARES, Marcio. A ontologia de Platão: um estudo das formas no Parmênides. Passo Fundo: Ed. da UPF, 2001. 